\title{
Effect of Chronic Admnistration of Ficus Thonningii on Depression and Motor Coordination in CD-1 Mice.
}

\author{
Aduema, $\mathbf{W}^{\mathbf{1}^{*}}$, Amah, A.K. ${ }^{2}$, Adebayo O G ${ }^{\mathbf{1}}$, Vidona, $\mathrm{WB}^{3}$ \\ ${ }^{I}$ Department of Human Physiology, PAMO, University of Medical Sciences, Port Harcourt, Rivers State, \\ Nigeria. \\ ${ }^{2}$ Department of Human Physiology, Imo State University, Imo State, Nigeria. \\ ${ }^{3}$ Department of Human Anatomy, Edo State University, Iyamo, Nigeria.
}

*Corresponding Author: Aduema, W, Department of Human Physiology, PAMO, University of Medical Sciences, Port Harcourt, Rivers State, Nigeria.

\begin{abstract}
The effect of ficus thonningii depression and motor coordination was investigated using 30 Adult Swiss mice weighing between 18 -21g, were divided into 3 groups containing 10 mice per group. Before the neurobehavioral parameters were assessed, the LD50, phytochemical screenings of the plant were determined. Group 1( control),received normal rat feed while, group 2(low dose )were administered with ficus thoninngii extract at a dose of $15 \mathrm{mg} / \mathrm{kg}$, and group 3 being the high dose were administered with ficus thoninngii extract at a dose of 30mg/kg, this administration lasted for 21 days. All animals were allowed clean drinking water. Beam walking apparatus was used to assess motor coordination while the forced swim test was used for depression. The results showed that the low and high dose administered ficus thonningii showed better motor coordination when compared to the control because the distance covered and the latency of fall was significantly longer compared to control $(P<0.05)$. Similarly, the frequency of foot slip was significantly low in the low and high dose group compared to control $(P<0.05)$.Forced swim test showed on significant difference among the groups.Therefore,chronic administration of the ficus thonningii improves motor coordination but does not affect depression.
\end{abstract}

Keywords: ficus thonnngii, beam walking, force swim, depression, motor coordination, mice

\section{INTRODUCTION}

$F$. thonningii is a well-known ornamental tree that is also used in improving agroforestry systems. Its leaves are used as fodder and its bark is used for making bark cloth. Like many woody trees, (Orwa et al., 2009). Ficus thonningii is extensively used by ethnomedical practitioners for treating various ailments and all part of this plant are medicinally useful, the latex-rich leaves are preferred because latex has been traditionally associated with potency (Ahur et al., 2010). Macerations of fresh $F$. thonningii leaves, taken orally, have been used by traditional healers for treating diarrhoea, gonorrhoea and diabetes mellitus (Njoronge and Kibunga, 2007. Leaf extracts are also used for treating bronchitis and urinary tract infections (Cousins and Huffman, 2002; Bah et al., 2006). In Nigeria, a maceration of the leaves is used for treating stomach pains, gastric ulcers and other stomach conditions in animals (Nwude and Ibrahim, 1980). The leaves can also be used for treating liver disorders and disease conditions associated with jaundice (Ahur et al., 2010). Other medicinal uses of the leaves reported include treatment of bone movement disorders, ringworm,etc (Moshi et al., 2009; Alawa et al., 2002). It contains various biologically active compounds such as alkaloids, terpenoids, flavonoids, tannins and essential ( Ndukwe et al., 2007 ; Usman et al., 2010; Greenham et al., 2007 ) . Studies have shown that the bark of the plant is important in local medicine and has been used in the treatment of cold, sore throat, dysentery, constipation, nose bleed, stimulation of lactation etc. Little or no studies have been recorded on the effect officus thionningii on neurobehavioral despair and motor coordination. Therefore, there is the need to find out the effect of this plant on motor coordination and depression using CD-1 mice as experimental animals. 

Mice.

\section{Materials AND Methods}

\section{Animals}

Thirty adult CD-1mice were bought from the Department of veterinary Medicine University of Agriculture, Umudike, and Abia State and was then transported to Department of Physiology, Abia state university, Uturu. The mice weighing between 18-21g were kept in the animal house of the Department of Physiology, Abia State University Uturu and were housed in groups of 3 (control, low dose and high dose) in plastic cages, maintained under standard dark-light cycle. Food and water were available ad libitum. All rules applying to animal safety and care were observed. Acclimatization lasted for 14 days.

\section{Experimental design}

Animals were identified using identity cards attached to each group containing 10 mice each among the three groups. Group 1 which is the control, received normal rat chow while Group 2 and Group 3 which are the low and high dose groups were administered $15 \mathrm{mg} / \mathrm{kg}$ and $30 \mathrm{Mg} / \mathrm{kg}$ via cannula daily for a period of 21 days. However, the lethal dose $\left(\mathrm{LD}_{50}\right)$ of the F.thonningii was determined prior to administration using the method proposed by lorke(1983).

\section{Experimental protocols for motor coordination}

The mice were carried to the test room in their home cages. The mouse was removed from its home cage and placed at one end of the balance beam. After the mouse has secured its grip on the beam, the trial begins. The maximum length of the trial is five minutes. The mouse is tested under white light, during the dark phase. The beam is cleaned with $70 \%$ ethanol and permitted to dry between each trial. The following behavioral parameters were measured,

Distance travelled: The number of line crosses.

Foot Slips: Number of times one of the mouse's back feet slips from the beam

Number of turns: Frequency that the animal reversed direction

Latency to fall: Time at which the animal fell off of the beam. If a fall occurred the animal was not placed back on the beam but was returned to the home cage. The trial was not repeated.

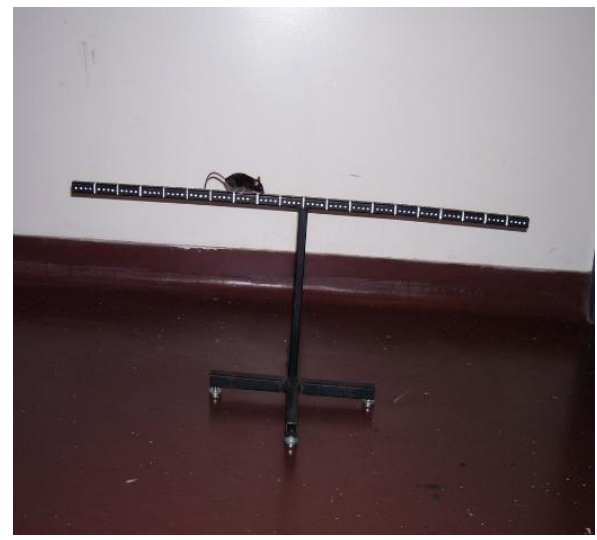

Beam walking apparatus

\section{Experimental protocols to test for depression}

A $2 \mathrm{~L}$ glass cylinder was filled with water at room temperature (approximately $25 \pm 2^{\circ} \mathrm{C}$ ). The cylinder is $19-\mathrm{cm}$ tall, $10-\mathrm{cm}$ in diameter and filled to $13-\mathrm{cm}$ (the $1600-\mathrm{mL}$ point) with tap water and allowed to sit overnight to achieve room temperature (Roy et al., 2007).

Mice should not be able to touch the bottom of the cylinder with their tails, as this may alter their behavior. Mice are picked up from their home cages in a plastic container with holes in the bottom to let out water, and are individually dropped (placed in, head downward, trying to ensure that the mouse's head does not go underwater) into the glass cylinder and observed for immobility for one 6min trial. Immobility is defined as the cessation of all movements except those necessary to stay afloat, such as paddling lightly with one. A stopwatch was used to record immobility. 


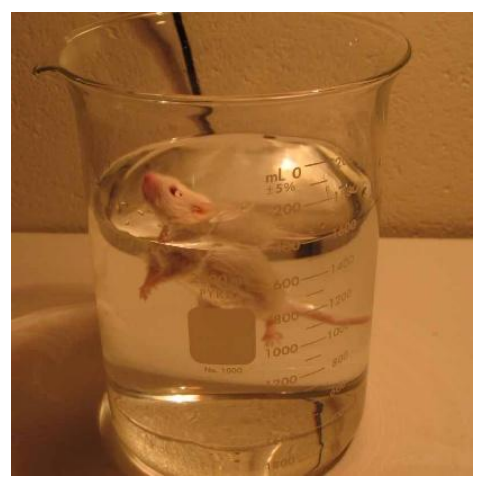

Test set up forced swim test

\section{Statistical analysis}

Data Obtained from the experiments were statistically analyzed using Microsoft excel, with factorial ANOVA/T-test in the statistics programme start view version for Windows or Mac. A Post-hoc comparison was also done using the student \pm Newman-keuls design. Values were represented as Mean \pm SEM and a "P" value less than 0.05 , was considered as significant.

\section{RESUltS}

\section{Behaviors scored during beam walking \\ Frequency of turn}

The frequency of turns for the low and high dose administered ficus thonningii were $35.82 \pm 7.04$ and $38.64 \pm 3.31 / 5$ mins was significantly higher $(\mathrm{P}<0.05)$ compared to control which was $22.37 \pm 4.82$. Fig 1 Foot slip

The frequency of foot slips in the low and high dose groups were $3.21 \pm 1.02$ and $2.53 \pm 0.32 / 5 \mathrm{mins}$ was significantly lower $(\mathrm{P}<0.05)$ compared to control which was $6.38 \pm 1.14 / 5 \mathrm{mins}$ respectively. Fig 2 .

\section{Distance covered}

The distance covered by the low and high dose groups of mice were $42.69 \pm 2.99$ and $58.80 \pm 7.46 / 6 \mathrm{mins}$ which as significantly higher $(\mathrm{P}<0.05)$ compared to the control group which was 25.50 $\pm 8.34 / 6 \mathrm{mins}$.Fig 3 .

\section{Latency of fall}

The latency of fall of the different experimental groups are as follows: $8.04 \pm 7.08 ; 12.25 \pm 1.12$ and $16.20 \pm 0.02$ seconds for mice fed control, low and high dose diets respectively. The latency of fall was longer for the low and high dose groups of mice compared to control at $\mathrm{p}<0.05$. (Figure 4).

\section{Behaviors scored in the forced swim test}

\section{Float latency}

The float latency for the low and high dose groups were $103.49 \pm 5.20$ and $104.02 \pm 2.60$ seconds which was significantly different compared to the control which was $100.62 \pm 8.80$ seconds. See fig 5 .

\section{FREQUENCY OF TURNS/5MINS}

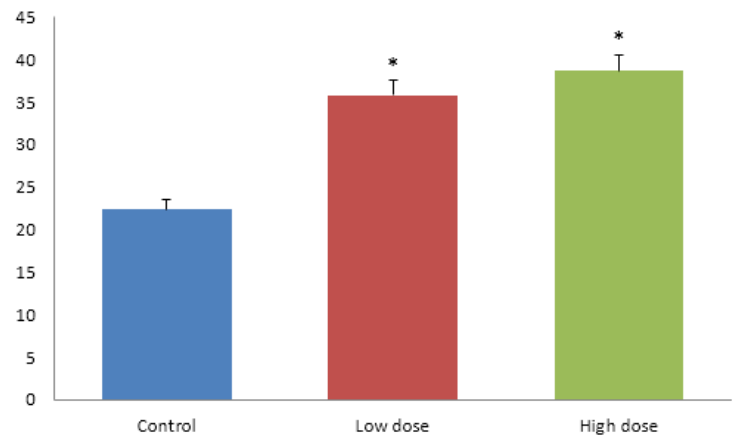

Fig1. frequency of turns in the beam walking test among the experimental groups within 5mins.Values are expressed as the mean, standard error of mean $( \pm), n=10$;

$* P<0.05$ compared to control. 

Mice.

\section{FREQUENCY OF FOOT SLIPS/5MINS}

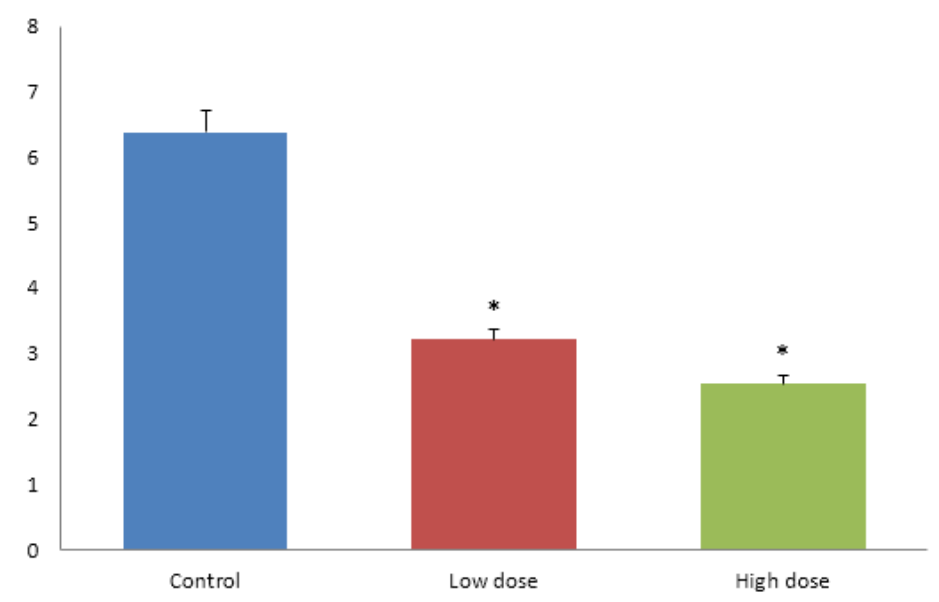

Fig2. frequency of foot slips in the beam walking test within 5minutes among the experimental groups. Values are expressed as the mean, standard error of mean ( \pm ), $n=10$;

$* P<0.05$ compared to control.

\section{DISTANCE COVERED /5MINS}

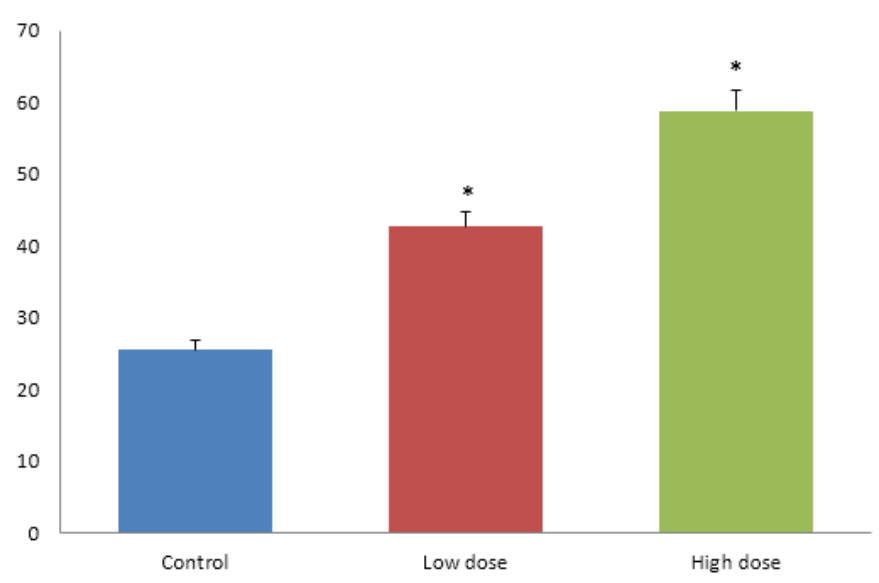

Fig3. distance covered in the beam walking test within 5minutes among the experimental groups. Values are expressed as the mean, standard error of mean $( \pm), n=10$;

$* P<0.05$ compared to control.

\section{LATENCY OF FALLS (SECS)}

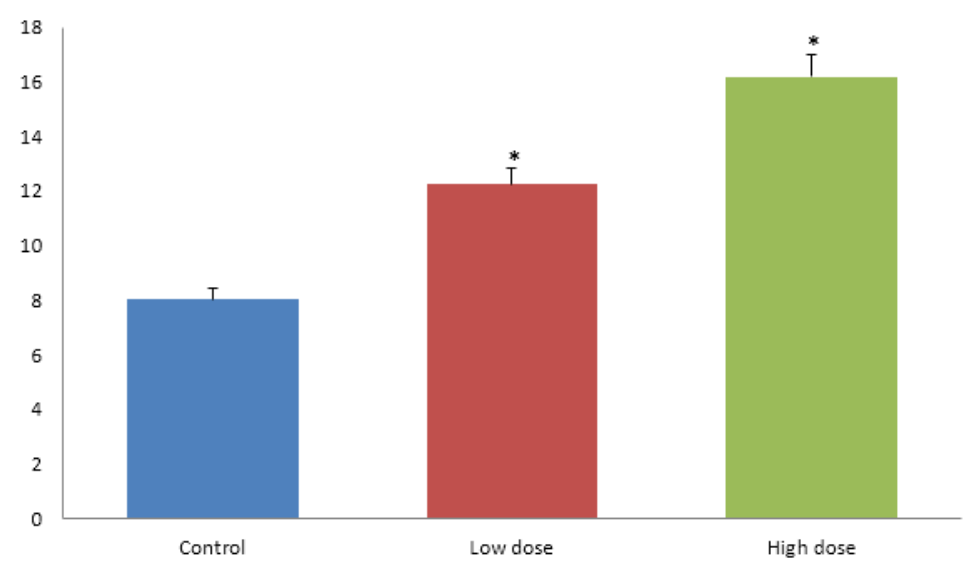

Fig4. latency of falls in the beam walking test among the experimental groups. Values are expressed as the mean, standard error of mean $( \pm), n=10$;

$*_{p}<0.05$ compared to control. 


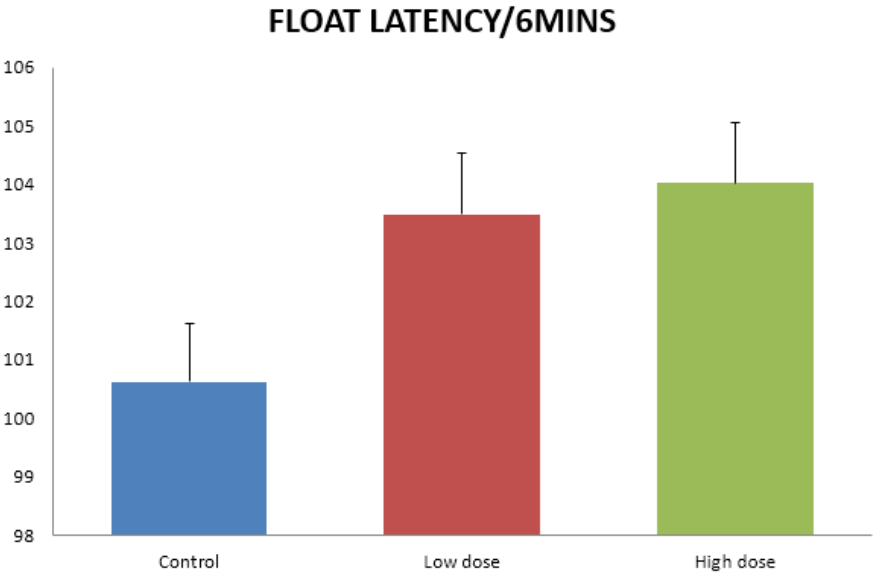

Fig5. float latency in the forced swim test within 6 minutes among the different experimental groups. Values are expressed as the mean, standard error of mean ( \pm ), $n=10$;

$* P<0.05$ compared to control.

\section{DISCUSSION}

Beam walking is a test for motor coordination and balance (Hyde et al., 2001; Easton et al., 1998; Hymson et al., 1982 ;). The task involved the ability of the mice to learn to maneuver their way and stay on the beam balance for as long as possible. The results in beam walking showed that the frequency of turn was significantly higher in the low and high dose groups of mice compared to the control. The distance covered group showed better motor coordination in the treated groups compared to control. During the foot slip test, the low and high dose groups of mice showed fewer foot slips when compared to the control. This indicates a high level of manoeuvrability in the beam, thus indicating better motor coordination and therefore the better the motor learning ability. ). The latency of fall in the groups of mice treated with the low and high dose was significantly longer when compared to their control for the period of training on the beam apparatus. This means that the animals in the test groups learned better to stay on the beam compared to their control.Therefore,chronic administration of ficus thonningii may have a stimulating effect on the cerebellum which is involved in learning adjustments that make motor coordination easier when a given task is performed over and over(Ganong et al.,2010) .

The force swim test in mice was developed to test rodents for immobility because it was discovered that rodents became immobile after an initial swimming activity in an inescapable situation. The duration of immobility is considered a measure of despair or depression. The force swim test showed no significant difference in the three experimental groups when compared. The results obtained showed that the mice in the different experimental groups showed equal level of depression when the duration of their immobility was considered.

\section{CONCLUSION}

Chronic administration of the leaves of ficus thonningii improves motor coordination but does not affect depression. If these results are applied in humans, then the leaves of this plant could be used in the control and management of ataxia, the animal model of Parkinson's disease.

\section{ACKNOWLEDGEMENT}

We acknowledged Mr. and Mrs. B.A.Aduema, for their wonderful support and inspiration.

\section{REFERENCES}

[1] Ahur VM, Madubunyi I, Adenkola AY and Udem SC (2010). The effect of acetyl acetate extract of Ficus thonningii (Blume) leaves on erythrocyte osmotic fragility and hematological parameters in acetaminophen-treated rats. Com Clin Pathol; 10:1107-1111.

[2] Alawa J P, Jokthan GE and Akut K. 2002; Ethnoveterinary medical practice for ruminants in the subhumid zone of the northern Nigeria. Prev Vet M54ed:79-90.

[3] Bah S, Diallo D, Dembele B.and Paulsen S (2006). Ethnopharmacological survey of plants used for the treatment of schistosomiasis in Niono district, Mali. J Ethnopharmacology; 105:387-399. 

Mice.

[4] Easton, J., Delvulder, B.,Jouen, F and Lalonde, Role of an enriched environment on the restoration of behavioural deficits in Lurcher mutant mice. Developmental Psychobiology1998,35,291-303.

[5] Cousins D, Huffman MA 2002. Medicinal properties in the diets of gorillas: an ethno-pharmacological evaluation. Afr Study Monogr; 23:65-89.

[6] Ganong, W.F., Barrette, K.E., Berman, S.M., Boitano, S. and Brooks, H.l.Ganong'sReview on Medical Physiology, 2010, (pp.76-230).New Delhi: McGraw-Hill.

[7] Greenham JR, Grayer RJ, Harbone JB, Reynolds V 2007. Intra- and Interspeficic variations in vacuolar flavonoids among Ficus species from the Budongo forest, Uganda. Biochem System Ecol; 35:81-90.

[8] Hyde, L, A., Crnic, L.S.Pollock, A \&Bickford, P.C. Motor learning in Ts65Dn mice, a model for Down syndrome. Developmental Psychobiology, 38, 33-45, 2001.

[9] Hymson,D.L.andHydes,M.D.Evidence that ethanol- induced impairment of Rod-rod performance is not mediated by opioid mechanisms. Progress of Neuro-Psychopharmacology and Biological Psychiatry, 1982, 6,159-165.

[10] Lorke, D. (1983). A new approach to practical acute toxicity test. Arch. Toxicol. 54: 275 - 286.

[11] Moshi MJ, Otieno DF, Mbabazi PK, Weisheit A 2009.The ethnomedicine of the Haya people of Bugabo ward, Kagera Region, North-western Tanzania. J.Ethnobiol Ethnomed; 5:24.

[12] Njoronge GN, Kibunga JW 2007. Herbal medicine acceptance, sources and utilization for diarrhea management in a cosmopolitan urban area (Thika, Kenya). Afr J Ecol; 45:65-70.

[13] Nwude N, Ibrahim MA 1980. Plants used in traditional veterinary medical practice in Nigeria. J Vet Pharmacol Ther; 3:271-273.

[14] Orwa C, A Mutua, Kindt R, S Anthony. 2009 Agroforestree database: a tree reference and selection guide.

[15] Roy, M., David, N., Cueva, M. and Giorgetti, M. (2007). A study of the involvement of melaninconcentrating hormone receptor 1 (MCHR1) in murine models of depression. Biological Psychiatry, 61: 174-180.

[16] Usman H, Abdulrahman FI, Usman A 2009. Qualitative phytochemical screening and in vitro antimicrobial effects of methanol stem bark extract of Ficus thonningii (Moraceae) AJTCAM.6:289-295.

Citation: Aduema W, et.al., (2020). Effect of Chronic Admnistration of Ficus Thonningii on Depression and Motor Coordination in CD-1 Mice. International Journal of Medicinal Plants and Natural Products (IJMPNP), 6(1), pp.9-14. http://dx.doi.org/ 10.20431 /2454-7999.0601003

Copyright: (C) 2020 Authors, this is an open-access article distributed under the terms of the Creative Commons Attribution License, which permits unrestricted use, distribution, and reproduction in any medium, provided the original author and source are credited. 